\title{
Laboratory Evaluation of Neem formulation bioactivity against Crocidolomia pavonana $\mathbf{F}$. larvae
}

\author{
R.A.M. Ramadhan, Neneng S. Widayani, Lindung T. Puspasari, Yusup Hidayat, Danar Dono* \\ Department of Plant Pests and Diseases, Agriculture Faculty, Universitas Padjadjaran, Jatinangor, West Java, Indonesia, \\ 45363 \\ *Corresponding Author: danar.dono@unpad.ac.id
}

\begin{abstract}
This study aims to evaluate the bioactivity of the formulation of Neem 50 EC against Crocidolomia pavonana larvae in the laboratory. The study using six treatments and three replications. The treatment consisted of the formulation of neem $50 \mathrm{EC}$ at concentrations of $0.3 \%, 0.5 \%, 0.8 \%, 1.3 \%, 2.3 \%$, and control. The treatment was done by leaf feeding method and tested on C. pavonana instar II. The results of the research showed that the formulation of neem $50 \mathrm{EC}$ at concentration of $2.3 \%$ caused mortality of $C$. pavonana larvae with mortality rate of $95 \%$ and has $\mathrm{LC}_{50}$ value aqual to $0.83 \%$. Neem formulation can inhibit the development of $C$. pavonana larvae from instar I to instar IV, decrease food consumption, and decrease the dry weight of $C$. pavonana larvae instar IV.
\end{abstract}

Keywords: Azadirachta indica, Bioactivity, Crocidolomia pavonana, neem formulation

\section{ABSTRAK}

Evaluasi Laboratorium Bioaktivitas Formula Mimba Terhadap Larva Crocidolomia pavonana F.

Penelitian ini bertujuan untuk mengevaluasi bioaktiviitas formula mimba terhadap larva Crocidolomia pavonana di laboratorium. Penelitian menggunakan 6 perlakuan yang diulang tiga kali. Perlakuan terdiri dari kontrol, formula Mimba konsentrasi $0,3 \%, 0,5 \%, 0,8 \%, 1,3 \%$, dan 2,3\%. Pengujian dilakukan dengan metode pencelupan daun pakan berperlakuan dan diujikan pada $C$. pavonana instar II. Hasil penelitian menunjukkan bahwa Formula Mimba 2,3\% dapat meningkatkan mortalitas larva $C$. pavonana dengan tingkat mortalitas mencapai $95 \%$ populasi dan nilai $\mathrm{LC}_{50}$ sebesar 0.82973 . Formula Mimba dapat menghambat perkembangan larva C. pavonana dari instar I hingga instar IV, menurunkan konsumsi pakan, dan menurunkan bobot kering larva instar IV.

Kata Kunci: Azadirachta indica, Bioaktivitas, Crocidolomia pavonana, Formula Mimba

\section{PENDAHULUAN}

Hama merupakan suatu organisme penganggu yang dapat menurunkan kualitas maupun kuantitas produk pertanian. Umumnya usaha pengendalian hama di Indonesia menggunakan pestisida sintetik. Penggunaan pesisida sintetik yang kurang bijaksana dapat menimbulkan berbagai dampak negatif seperti pencemaran tanah, air, dan udara, timbulnya resistensi dan resurgensi hama, terjadinya ledakan hama sekunder, rusaknya keseimbangan ekosistem, serta timbulnya dampak buruk bagi kesehatan masyarakat (Retno, 2006).

Berbagai usaha telah dilakukan untuk meminimalisir dampak negatif akibat penggunaan pestisida sintetik yang kurang bijaksana. Salah satu usaha untuk meminimalisir dampak negatif penggunaan pestsida sintetik dilakukan dengan cara memanfaatkan pestisida nabati yang lebih ramah lingkungan.

Mimba (Azadirachta indica) merupakan salah satu tumbuhan yang telah banyak diteliti dan berpotensi sebagai pestisida nabati. Tumbuhan mimba dapat memproduksi senyawa azadirakhtin yang bersifat antifeedant serta dapat menganggu fisiologi serangga (Samsudin, 2011). Senyawa azadirakhtin yang dihasilkan dari ekstrak biji $A$. indica dapat memberikan gangguan pada reseptor serangga, gangguan tersebut menyebabkan gangguan preferensi makan serangga (Simmonds \& Blaney, 1983; Mordue \& Nisbet, 2000).

Penelitian ini bertujuan untuk menguji bioaktiviitas formula mimba $50 \mathrm{EC}$ terhadap larva Crocidolomia pavonana.

\section{BAHAN DAN METODE}

Percobaan ini dilaksanakan di laboratorium pestisida dan toksikologi lingkungan, Departemen Hama Dan Penyakit Tumbuhan, Fakultas Pertanian, Universitas Padjadjaran. Metode percobaan menggunakan metode eksperimental. Percobaan disusun dalam Rancangan Acak Lengkap (RAL) yang tersusun dari 6 perlakuan serta diulang sebanyak 3 kali pengulangan. Perlakuan yang diujikan yaitu kontrol, formula Mimba 50 EC 0,3\%, 0,5\%, 0,8\%, $1,3 \%$, dan $2,3 \%$

Pengujian dilakukan dengan metode pencelupan daun pakan berperlakuan (no choice test). Pakan yang digunakan berupa daun kubis berukuran 4 $\mathrm{x} 4 \mathrm{~cm}$ yang dicelupkan ke dalam larutan formula selama 20 detik sehingga seluruh bagian pakan terbasahi secara merata. Selanjutnya daun dikeringanginkan dan dimasukkan ke dalam cawan petri beriameter $9 \mathrm{~cm}$ yang telah diberi alas berupa kertas tisue. Kedalam setiap cawan petri dimasukkan 10 ekor larva $C$. pavonana instar II dengan 
menggunakan kuas halus. Pemberian pakan berperlakuan dilakukan selama 48 jam ( 2 × 24 jam), selanjutnya pakan diganti dengan pakan tanpa perlakuan hingga larva mencapai instar IV. Pengamatan dilakukan setiap hari hingga larva mencapai instar IV. Parameter yang diamati dalam penelitian ini adalah mortalitas, perkembangan, konsumsi pakan, dan bobot kering larva $C$. pavonana.

Data hubungan konsentrasi dan kematian larva dianalisis menggunakan analisis probit (Finney 1971). Data waktu perkembangan disajikan dalam bentuk nilai rata-rata dan standar deviasi, sedangkan data konsumsi pakan dan bobot larva instar IV dianalisis dengan analisis sidik ragam (Analysis of Variance). Perbedaan antar perlakuan pada konsumsi pakan dan bobot larva instar IV diuji lanjut dengan menggunakan uji jarak berganda Duncan pada taraf kepercayaan $5 \%$.

\section{HASIL DAN PEMBAHASAN Mortalitas Larva}

Larva $C$. pavonana yang diberi perlakuan formula mimba 50 EC berbagai konsentrasi menunjukkan respon mortalitas yang meningkat sesuai dengan banyaknya formula yang diberikan.
Nilai mortalitas larva $C$. pavonana meningkat tajam pada hari ke-2 setelah perlakuan dan mulai stabil pada hari ke-8 setelah perlakuan (Gambar 1).

Hasil analisis probit dengan menggunakan program POLO-PC menunjukkan bahwa nilai LC menurun pada 2 HSP (hari setelah perlakuan) hingga 14 HSP (Tabel 1). Penurunan nilai LC dari formula Mimba 50 EC mengindikasikan peningkatan nilai toksisitas formula tersebut. Peningkatan signifikan dari jumlah kematian serangga uji pada 2 HSP menindikasikan bahwa formula Mimba 50 EC memiliki efek knockdown (Ramadhan dkk., 2016)

Penghitungan nilai $\mathrm{LC}_{50}$ dihitung dengan pengamatan berdasarkan waktu setelah pengaplikasian formula mimba 50 EC dengan selang kepercayaan $95 \%$. Hasil analisis probit menunjukkan bahwa nilai LC menurun pada 2 HSP hingga 8 HSP, hal tersebut menunjukkan efek dari senyawa toksik yang terdapat dalam formula mimba 50 EC dapat meningkatkan nilai mortalitas larva $C$. pavonana hingga hari ke-8 setelah pengaplikasian. Besaran nilai $\mathrm{LC}_{50}$ pada 8 HSP dapat dijadikan acuan nilai toksisitas dari formula mimba 50 EC terhadap larva C. pavonana, yaitu sebesar 0,82973 yang dihitung dengan selang kepercayaan $95 \%$ (Tabel 1).

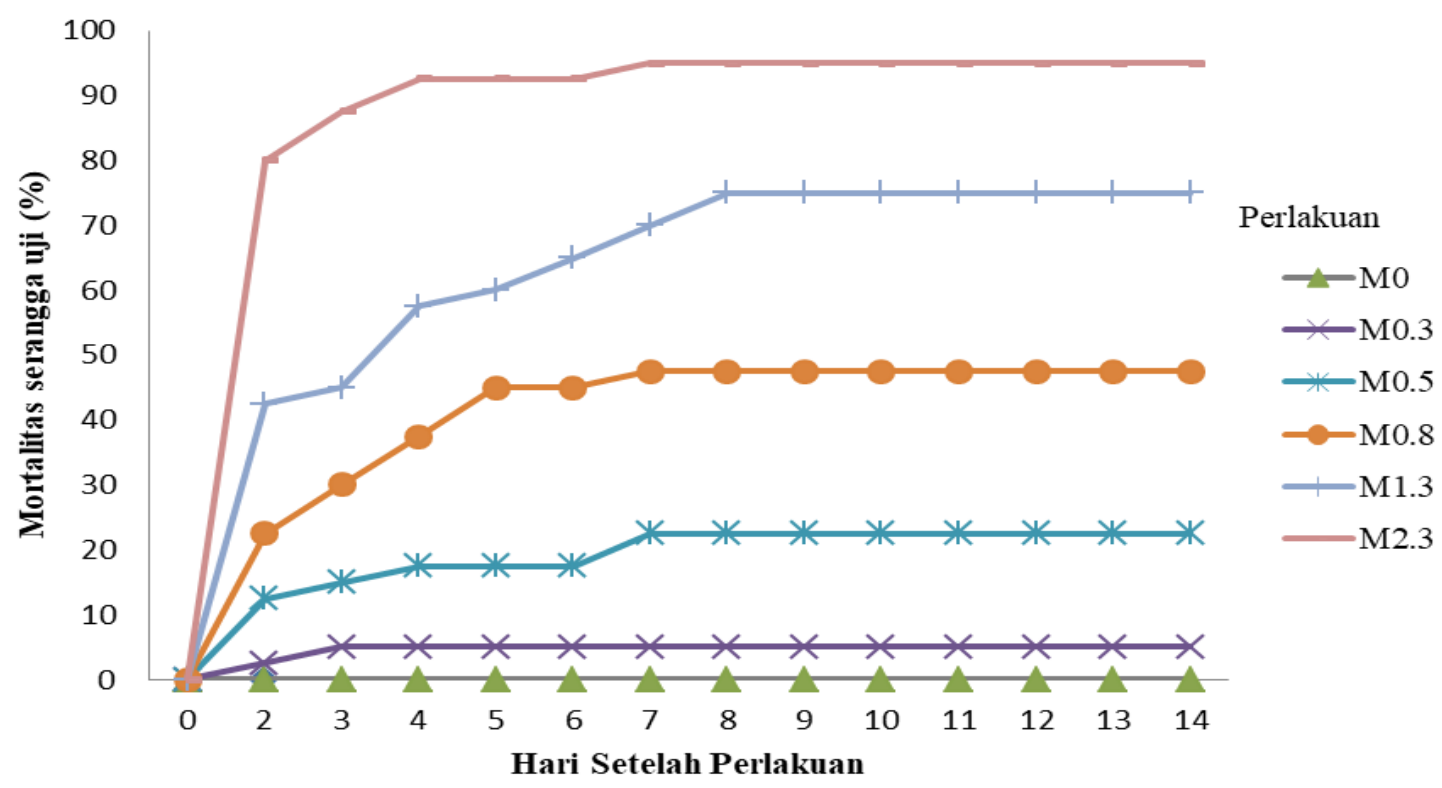

Gambar 1. Mortalitas kumulatif Crocidolomia pavonana dengan perlakuan berbagai taraf konsentrasi formula mimba 50 EC.

Keterangan: MO: Kontrol; M0,3: Mimba 50 EC 0,3\%; M0,5: Mimba 50 EC 0,5\%; M0,8: Mimba 50 EC 0,8\%; M1,3: Mimba 50 EC 1,3\%; M 2.3: Mimba 50 EC 2,3\%.

\section{Perkembangan larva}

Lama perkembangan larva dihitung berdasarkan waktu (hari) yang ditempuh larva instar I hingga instar II, instar I hingga instar III, dan instar I hingga instar IV. Formula mimba 50 EC dapat menghambat perkembangan larva $C$. pavonana instar I hingga instar IV, seiring dengan peningkatan konsentrasi formula yang digunakan sebagai perlakuan. Formula mimba 50 EC dapat menghambat perkembangan larva $C$. pavonana dengan memperpanjang waktu perkembangan larva sebesar 1 hingga 4 hari. Pada perlakuan kontrol perkembangan larva instar I hingga instar IV membutuhkan waktu selama 7 hingga 8 hari sedangkan pada perlakuan formula mimba $50 \mathrm{EC} \mathrm{2,3 \%}$ membutuhkan waktu selama 10 hingga 11 hari (Tabel 2). 
Tabel 1. Hasil analisis regresi probit toksisitas formula mimba $50 \mathrm{EC}$ terhadap larva $C$. pavonana berdasarkan waktu

\begin{tabular}{|c|c|c|c|c|c|c|c|}
\hline Waktu & $\mathrm{a} \pm \mathrm{SE}$ & $\mathrm{b} \pm \mathrm{SE}$ & $\mathrm{LC}_{50}$ & $\mathrm{SK}_{95}$ & $\mathrm{LC}_{95}$ & $\mathrm{SK}_{95}$ & $\mathrm{~g}$ \\
\hline $2 \mathrm{HSP}$ & $0,391 \pm 0,107$ & $3,031 \pm 0,408$ & 1,346 & $1,144-1,647$ & 4,697 & $3,319-8,342$ & 0,070 \\
\hline 3 HSP & $0,211 \pm 0,105$ & $3,002 \pm 0,392$ & 1,175 & $2,070-8,003$ & 4,151 & $2,546-12,825$ & 0,179 \\
\hline $4 \mathrm{HSP}$ & $0,260 \pm 0,107$ & $3,289 \pm 0,405$ & 0,998 & $0,863-1,169$ & 3,157 & $2,392-4,871$ & 0,058 \\
\hline 5 HSP & $0,751 \pm 0,108$ & $3297 \pm 0,404$ & 0,949 & $0,821-1,108$ & 2,992 & $2,282-4,561$ & 0,058 \\
\hline $6 \mathrm{HSP}$ & $0,117 \pm 0,109$ & $3,392 \pm 0,410$ & 0,923 & $0,801-1,073$ & 2,819 & $2,175-4,205$ & 0,056 \\
\hline 7HSP & $0,244 \pm 0,112$ & $3,506 \pm 0,419$ & 0,852 & $0,740-0,983$ & 2,509 & $1,963-3,648$ & 0,055 \\
\hline 8 HSP & $0,294 \pm 0,115$ & $3,627 \pm 0,428$ & 0,830 & $0,723-0,954$ & 2,357 & $1,865-3,361$ & 0,053 \\
\hline
\end{tabular}

Keterangan

a : intersep garis regresi

b : kemiringan garis regresi (Slope)

SE : standar eror
LC : lethal concertration (respon kematian)

SK : selang kepercayaan

$\mathrm{G} \quad$ : tingkat keteleitian penduga

Tabel 2. Lama perkembangan larva Crocidolomia pavonana setelah pengaplikasian formula mimba $50 \mathrm{EC}$ berbagai konsentrasi

\begin{tabular}{|c|c|c|c|c|c|c|}
\hline \multirow[t]{2}{*}{ Perlakuan } & \multicolumn{6}{|c|}{ Perkembangan $(\mathrm{x} \pm \mathrm{SD})$ hari } \\
\hline & Instar I-II & $\mathrm{n}$ & Instar I-III & $\mathrm{n}$ & Instar I-IV & $\mathrm{n}$ \\
\hline Kontrol & $2,10 \pm 0,304$ & 40 & $3,75 \pm 0,439$ & 40 & $7,50 \pm 0,506$ & 40 \\
\hline Mimba $0,3 \%$ & $2,21 \pm 0,413$ & 38 & $4,26 \pm 0,644$ & 38 & $7,42 \pm 0,642$ & 38 \\
\hline Mimba $0,5 \%$ & $2,65 \pm 0,485$ & 34 & $5,00 \pm 0,632$ & 31 & $8,58 \pm 0,720$ & 31 \\
\hline Mimba $0,8 \%$ & $3,64 \pm 0,569$ & 25 & $4,91 \pm 0,426$ & 22 & $9,14 \pm 0,964$ & 21 \\
\hline Mimba $1,3 \%$ & $3,06 \pm 0,243$ & 17 & $6,00 \pm 0,739$ & 12 & $10,50 \pm 0,850$ & 10 \\
\hline Mimba $2,3 \%$ & $4,67 \pm 0,577$ & 3 & $7,50 \pm 0,707$ & 2 & $13,50 \pm 0,707$ & 2 \\
\hline : Rata-ra & ot larva $(g)$ & & & & & \\
\hline : Jumlah & asi C. pavonana & & & & & \\
\hline : Standar & & & & & & \\
\hline
\end{tabular}

Senyawa azadirakhtin mempu menganggu hormon-hormon yang mengatur perkembangan hampir seluruh ordo serangga yang mengakibatkan abnormalitas perkembangan dan abnormalitas fisiologi serangga (Subrahmanyam, 1990). Azadirakhtin dapat menganggu perkembangan serta dapat menyebabkan abnormalitias morfologi pada larva lepidoptera dan nimfa orthoptera (Samsudin, 2011). Kraiss \& Cullen (2008) melaporkan bahwa senyawa azadirakhtin dapat menganggu perkembangan dan fekunditas imago betina pada ordo hemiptera dan coleoptera. Senyawa azadirakhtin dapat menghambat perkembangan sel-sel dalam tubuh serangga lepidoptera dengan mekanisme penghambatan proses mitosis yang terjadi di tingkat selular (Salehzadeh et al., 2003).

\section{Bobot konsumsi pakan}

Bobot konsumsi pakan dihitung berdasarkan selisih bobot kering awal dikurangi bobot kering pakan setelah pengaplikasian (48 jam). Bobot konsumsi pakan dihitung dengan meggunakan faktor koreksi dengan perlakuan pengeringan daun dalam oven $90^{\circ} \mathrm{C}$ selama 48 Jam. Hasil uji bobot konsumsi pakan dianalisis menggunakan uji jarak berganda Duncan dengan taraf kepercayaan 5\% (Tabel 3).

Tabel 3. Rata-rata bobot konsumsi pakan C. pavonana setelah 48 jam perlakuan

\begin{tabular}{ll}
\hline Perlakuan & Rata-rata bobot konsumsi pakan $(\mathrm{g})$ \\
\hline Kontrol & $0,021325 \mathrm{~b}$ \\
Mimba 50 EC 0,3\% & $0,016625 \mathrm{ab}$ \\
Mimba 50 EC 0,5\% & $0,015300 \mathrm{ab}$ \\
Mimba 50 EC 0,8\% & $0,011050 \mathrm{a}$ \\
Mimba 50 EC 1,3\% & $0,009400 \mathrm{a}$ \\
Mimba 50 EC 2,3\% & $0,007325 \mathrm{a}$ \\
\hline
\end{tabular}

Keterangan: Angka yang diikuti notasi yang sama memiliki arti tidak berbeda nyata menurut uji Duncan pada taraf kepercayaan $5 \%$. 
Berdasarkan uji jarak berganda Duncan pada taraf kepercayaan $5 \%$ perlakuan kontrol, perlakuan Mimba 50 EC 0,3\% dan Mimba 50 EC 0,5\% tidak berbeda nyata. Seluruh perlakuan mimba berbagai konsentrasi juga tidak menampilkan perbedaan yang signifikan, akan tetapi perlakuan kontrol berbeda nyata terhadap perlakuan Mimba 50 EC 0,8\%, 1,3\%, dan 2,3\%. Perlakuan Mimba 50 EC konsentrasi 0,8\%, $1,3 \%$, dan $2,3 \%$ dikatakan efektif untuk menurukan bobot konsumsi pakan rata-rata larva $C$. pavonana. Menurut Suryaningsih \& Hadisoeganda (2007) mimba memiliki kandungan limonoid dan quadinoid yang berfungsi sebagai penolak makan. Kandungan meliantriol juga membuat hama enggan mendekat (Mardiningsih dkk., 2010). Sifat penolak makan tersebut mungkin yang menyebabkan konsumsi makan C. pavonana pada penelitian ini lebih rendah setelah pemaparan insektisida formula mimba. Pengujian mimba lainnya terhadap larva S. litura menunjukkan respon antifeedant berdasarkan bobot konsumsi pakan yang rendah oleh perlakuan produk komersial vijaya neem 0,2 \% dan ekstrak biji mimba 5\% (Razak et al., 2014).

\section{Bobot kering larva instar IV}

Larva $C$. pavonana yang bertahan hingga mencapai instar IV dikeringkan dengan menggunakan oven pada suhu $95^{\circ} \mathrm{C}$ selama 48 jam. Setelah larva dikeringkan kemudian dihitung bobot keringnya dengan menggunakan timbangan analitik dengan ketelitian 6 angka di belakang koma. Bobot larva kemudian dirata-ratakan dengan cara membagi bobot larva total dengan jumlah larva yang dikeringkan. Data bobot kering larva $C$. pavonana instar IV kemudian diuji lanjut menggunakan uji jarak berganda Duncan pada taraf kepercayaan 5\% (Tabel 4).

Berdasarkan hasil uji jarak berganda Duncan pada taraf kepercayaan 5\% rata-rata bobot kering larva $C$. pavonana instar IV pada perlakuan kontrol berbeda nyata dengan seluruh perlakuan formula Mimba 50 EC. Perlakuan Mimba 50 EC 0,3\% tidak berbeda nyata dengan perlakuan Mimba 50 EC $0,5 \%$ dan berbeda nyata dengan perlakuanlan lainnya. Formula Mimba 50 EC $0,8 \%$ tidak berbeda nyata dengan perlakuan Mimba 50 EC 1,3\% dan berbeda nyata dengan perlakuan lainnya. Perlakuan Mimba 50 EC $2,3 \%$ berbeda nyata dengan seluruh perlakuan yang diujikan sekaligus merupakan perlakuan dengan respon terbaik terhadap penekanan bobot kering larva C. pavonana instar IV. Bobot kering larva C. pavonana yang rendah disebabkan oleh adanya efek tidak langsung dari perlakuan daun yang toksik (Mardiningsih dkk., 2010).

Tabel 4. Rata-rata bobot kering larva C. pavonana instar IV

\begin{tabular}{ll}
\hline Perlakuan & Rata-rata bobot larva $(\mathrm{g})$ \\
\hline Kontrol & $0,004150 \mathrm{~d}$ \\
Mimba 50 EC 0,3\% & $0,002800 \mathrm{c}$ \\
Mimba 50 EC 0,5\& & $0,002200 \mathrm{c}$ \\
Mimba 50 EC 0,8\% & $0,001525 \mathrm{~b}$ \\
Mimba 50 EC 1,3\% & $0,001250 \mathrm{~b}$ \\
Mimba 50 EC 2,3\% & $0,000300 \mathrm{a}$ \\
\hline
\end{tabular}

Keterangan: Angka yang diikuti notasi yang sama memiliki arti tidak berbeda nyata menurut uji Duncan pada taraf kepercayaan $5 \%$.

\section{KESIMPULAN}

Formula Mimba 50 EC 2,3\% mengakibatkan mortalitas larva $C$. pavonana yang terus meningkat pada 2 HSP hingga 8 HSP dengan mortalitas mencapai $95 \%$ populasi dan nilai $\mathrm{LC}_{50}$ sebesr 0,829 pada 8 HSP. Formula Mimba 50 EC dapat menghambat perkembangan larva $C$. pavonana dari instar I hingga instar IV, penghambatan tertinggi ditunjukkan oleh perlakuan Mimba 50 EC 2,3\% dengan kisaran hambatan perkembangan selama 1 hingga 4 hari. Formula Mimba 50 EC dapat menurunkan jumlah konsumsi pakan $C$. pavonana, perlakuan terbaik ditunjukkan oleh perlakuan Mimba
50 EC $0,8 \%, 1,3 \%$, dan 2,3\% dengan jumlah konsumsi pakan rata-rata sebesar 0,011 g, 0,09 g, dan 0,07 g. Formula Mimba 50 EC dapat menurunkan bobot kering larva instar IV, perlakuan Mimba 2,3\% menunjukkan hasil terbaik dengan nilai bobot kering larva rata-rata sebesar $0,0003 \mathrm{~g}$.

\section{UCAPAN TERIMA KASIH}

Penelitian ini dibiayai oleh Program Penelitian Riset Andalan Perguruan Tinggi dan Industri (RAPID) DP2M DIKTI Tahun 2016-2017 dengan peneliti utama Dr. Danar Dono, Ir., M.Si. 


\section{DAFTAR PUSTAKA}

Finney D.J. 1971. Probit Analysis, 3rd ed. Cambridge: Cambridge Univ Press. 336 pp.

Kraiss, H., \& E.M. Cullen. 2008. Insect growth regulator effects of azadirachtin and neem oil on survivorship, development and fecundity of Aphis glycines (Hemiptera: Aphididae) and its predator, Harmonia axyridis (Coleoptera: Coccinellidae). Journal Pest Management Sciences, Society of Chemical Industry. Pest Manag Sci 1526-498X/2008/\$30.00 Archived at http://orgprints.org/24349

Mardiningsih, T.L., C. Sukmana, N. Tarigan, \& S. Suriarti. 2010. Efektivitas insektisida nabati berbahan aktif azadirachtin dan saponin terhadap mortalitas dan intensitas serangan Aphis gossypii Glover. Bogor. Bul. Litro. 21(2): 171-183.

Mordue, A.J.L \& A.J. Nisbet. 2000. Azadirachtin from the neem tree Azadirachta indica: its action against insects. Department of Zoology, University of Aberdeen, Tillydrone Avenue, Aberdeen, AB24 2TZ Scotland.

Ramadhan, R.A.M., L.T. Puspasari, R. Meliansyah, R. Maharani, Y. Hidayat, \& D. Dono. 2016. Bioaktivitas formulasi minyak biji Azadirachta indica (A. Juss) terhadap Spodoptera litura F. Jurnal Agrikultura. 27 (1): 1-8.

Razak, T.A., T. Santhakumar, K. Mageswari, \& S. Santhi. 2014. Studies on efficacy of certain neem products against Spodoptera litura
(Fab.). Management of Spodoptera litura, J. Biopest. Vol.160-163.

Retno A. 2006. Usaha pengendalian pencemaran lingkungan akibat penggunaan pestisida pertanian. Jurnal Kesehatan Lingkungan. 3(1): 95-106.

Salehzadeh, A., A. Akhkha, W. Cushley, R.L.P. Adams, J.R. Kusel, \& R.H.C. Strang. 2003. The antimitotic effect of the neem terpenoid azadirachtin on cultured insect cells. Insect Biochemistry and Molecular Biology. 33: 681-689.

Samsudin. 2011. Biosintesa dan cara kerja azadirakhtin sebagai bahan aktif insektisida nabati. Balai Penelitian Tanaman Rempah dan Aneka Tanaman Industri. Prosiding Seminar Nasional Pestisida Nabati IV, Jakarta. Halaman 61-70.

Simmonds, M.S.J., and W.M. Blaney. 1983. Some neurophysiological effects of azadirachtin on lepidopterous larvae and their feeding response. Zoology Departement, Birkbeck College, London, England. Proccedings of 2nd International Neem Conference, Rauischholzhausen, Germany. Page 163179.

Subrahmanyam, B. 1990. Azadirachtin - A naturally occurring insect growth regulator. Proceding of Animal Sciences, Journal Animal Sciences. 99(3): 277-288.

Suryaningsih, E. and A. W.W. Hadisoeganda. 2007. Pengendalian hama dan penyakit penting cabai dengan pestisida biorasional. J.Hort. 17(3): 261-26

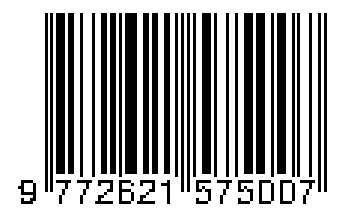

